\title{
Studies on development and storage stability of dehydrated pumpkin based instant soup mix
}

\author{
Anju K. Dhiman, Negi Vidiya, Attri Surekha, Ramachandran Preethi*
}

Department of Food Science and Technology, Dr YS Parmar University of Horticulture and Forestry, Nauni173230 (HP), INDIA

*Corresponding authors. E-mail: preethir615@gmail.com

Received: December 10, 2016; Revised received: April 19, 2017; Accepted: August 23, 2017

\begin{abstract}
The study was carried out to develop and standardize Instant Soup Mix (ISM) from dehydrated pumpkin powder and to evaluate nutritional (moisture, sugars, protein, $\beta$-carotene, fat, fibre and water activity) and sensory qualities (colour, texture, flavour and overall acceptability) for determining its shelf-life during a period of six month. It was packed in aluminium laminated pouches and was analyzed periodically for changes in quality. Among various recipes optimized for the development of soup mix, soup mix containing $20 \mathrm{~g}$ pumpkin powder, $5 \mathrm{~g}$ moong dhal, $15 \mathrm{~g}$ tomato powder, $11.4 \mathrm{~g}$ spices (salt and black pepper) and condiments (onion, garlic and ginger powder), $2 \mathrm{~g}$ dried pea, $2 \mathrm{~g}$ dried spinach, and $2 \mathrm{~g}$ dried carrot was selected as base recipe for addition of different starch source viz. rice, corn and potato @ $10 \mathrm{~g}$. From the nutritional analysis, it was observed that corn based Instant Soup Mix had higher $\beta$-carotene $(7.01 \mathrm{mg} / 100 \mathrm{~g})$ and protein $(12.65 \%)$ content, while fibre $(2.09 \%)$ was higher in soup mix containing rice starch. It was observed that on the basis of sensory evaluation corn based soup mix was more acceptable. Therefore, results of nutrition and sensory evaluation indicated that a good quality ISM can be prepared by using corn starch. During the six month of storage, there was about 5.49 per cent increase in moisture, 3.16 and 5.27 per cent decrease in protein and $\beta$-carotene, respectively, along with slight losses in total sugars, fat and sensory quality. Further, the product was stable for 6 months under ambient condition.
\end{abstract}

Keywords: $\beta$-carotene, Dehydration, Fibre, Pumpkin powder, Protein, Instant soup mix

\section{INTRODUCTION}

The anxious space of modern life and the increase in number of nuclear family with working women have determined changes in food preparation and in the habits of consumption. This has brought the scope of Instant Food Mixes which play a very important role in everyone's day-to-day life. The term 'instant food' means convenient food which is simple, easy and fast to prepare (Sowjanya and Manjula, 2016). The food habit in India is highly influenced by western culture at present and thus the usage of this food has greatly risen with their wide scope in catering industry and at homes. There are varieties of instant/ready-to-eat foods available in Indian market to choose from and these have been part of everyday life of many people. These include instant vegetable pulav mix (Semwal et al., 2001), instant khichadi mix (Patki et al., 2002), instant rice (Prapluettrakul et al., 2012), instant breakfast cereals (Akoth et al., 2012), instant weaning mix (Satter et al., 2013), instant rice noodles (Chandrajith et al., 2014), instant dhokla mix (Lohekar and Arya, 2014) and instant ragidosa (Sowjanya and Maanjula, 2016). The advantages of the dehydrated foods as instant food mixes is their protection from enzymatic and oxidative spoilage and flavour stability at room temperature over long periods of time (6 - 12 months). Also, they do not need refrigerator and have high quite nutritive value because of their high dietary fibre content and other health benefits.

Soup is the very fast form of cookery. It is probably one of man's oldest foods, since it must have developed about the time that boiling was found to be a way of cooking food. Soup is prepared by cooking meat or vegetables in stock or hot/boiling water, until the flavour is extracted, forming a broth. In modern world commercially prepared instant soup (such as canned, dehydrated, and frozen soups) are replacing homemade soup as preparing soup at home is a time consuming process. Instant soup can become an alternative food for breakfast because it could fulfil the adequacy of energy and nutrient requirement of the body. They are very practical in preparation and takes short time to serve (Sunyoto et al., 2012).

Pumpkin belongs to the family of Cucurbitaceae and is widely grown throughout the world (Dhiman et al., 2009).In India, the production of pumpkin, squash and gourd is 1.197 million MT from an area of 54'000 hectares (NHB, 2016). The production of cucurbits in Himachal Pradesh has been estimated to be 62,169 MT from an area of 2436 hectares (Anonymous, 2013). Pumpkin is sweet when fully mature with yellow to 
orange flesh which is rich in carotene, vitamins, minerals and dietary fibre (Yadavet al., 2010). $\beta$-carotene in pumpkin is converted to vitamin $\mathrm{A}$ in the body and thus plays a crucial role in the prevention of chronic diseases during adult life due to their antioxidant abilities (Blumberg, 1995). Pumpkin is being widely used in different food products as it is a rich source of fibre. The fibre content of pumpkin in different varieties viz. C. pepo, C. moschata and C.maxima was found to be $3.72 \mathrm{~g} / \mathrm{kg}, 7.41 \mathrm{~g} / \mathrm{kg}$ and $10.88 \mathrm{~g} / \mathrm{kg}$, respectively (Kim et al., 2012).The high amount of fibre, present in a pumpkin, is good for the bowel health of an individual. Thus the study presents the formulation of an instant soup mix with pumpkin flour and evaluating it for physico-chemical properties and sensory properties during storage the storage of six months under ambient condition.

\section{MATERIALS AND METHODS}

\section{Preparation of raw material}

Processing of pumpkin: Ripe pumpkin fruits were washed and cut into halves. After removing the seeds and fluffy portions, pumpkin was cut into slices. The slices were peeled and grated into shreds, which were steam blanched for 4 minutes followed by dipping in $500 \mathrm{ppm}$ of potassium metabisulphite $\left(\mathrm{K}_{2} \mathrm{H}_{2} \mathrm{O}_{5}\right)$ solution for 15 minutes. The shreds were then dried in a mechanical dehydrator at $60 \pm 2{ }^{\circ} \mathrm{C}$ for $8-10$ hours. The dried shreds were ground by using a grinder followed by sieving through 90 mesh metallic sieves to yield granulated powder. The prepared granulated powder was packed in Polyethylene Pouches for further use in preparation of Instant Soup Mix.

Processing of vegetables: The different vegetables like carrot, peas, tomato, carrot, spinach, onion, ginger and garlic were dried according to the method as described by Lal et al. (1986). After drying the vegetables were packed in PEP for further use in ISM.

Processing of rice, corn and potato starch: Rice and Corn flour were purchased from the local market and were used as the source of rice and corn starch. For the preparation of potato starch, potato was purchased from market and were peeled, washed, cut into pieces and was grinded in mixer grinder to get homogenous suspension. It was then strained through muslin cloth into a beaker and was allowed to stand for 2 hours for weigh deposition of starch at the bottom. Supernatant was removed and the starch was thoroughly washed and then dried in oven. It was finally ground into powder.

Standardization and product development: The recipe for preparation of ISM from pumpkin powder was developed and standardized by using different proportions of various ingredients. The best four recipes (Table 1) selected from preliminary studies were subjected to organoleptic evaluation by a panel of ten judges. The recipe which got the highest scoring for overall acceptability by a panel of judges was selected for preparation of ISM for further studies.

The selected recipe was blended with constant amount $(10 \mathrm{~g})$ each of different starch such as rice starch, corn starch and potato starch.

Standardization of instant soup mix: The method of preparation of ISM was standardized which includes roasting of pumpkin powder and moong dhal in an open pan and then allowing it to cool at room temperature. Different ingredients like tomato powder, ginger powder, garlic powder, onion powder, salt, black pepper powder, dehydrated spinach, carrot and peas were mixed properly. The mixture was divided into three different lots and blended with rice starch, corn starch and potato starch@10 g. The ISM was then packed in Aluminium Laminated Pouches (ALP) for further storage study of 6 months.

Formulations of pumpkin based Instant soup mix (ISM): For the preparation of Ready-to-Serve soup from ISM, required amount of water was added to pan for boiling. ISM was then added to boiling water. It was then continuously boiled till the required consistency was achieved. Butter can be added to enhance taste.

Sensory evaluation of the developed instant soup mix: Nine Point Hedonic scale method given by Amerine et al. (1965) was followed for conducting the sensory evaluation of pumpkin based Instant Soup Mix (ISM). The panel of ten judges evaluated the products for various sensory parameters such as colour, texture, flavour and overall acceptability depending upon the type of the product. Efforts were made to keep the same panel for sensory evaluation throughout the entire period of study. The samples were presented to the judges the way they are normally consumed.

Nutrient composition: Nutrient composition of the developed products were analysed using the standard procedures as listed below in Table 2 .

Shelf life study: Best recipe from the ISM prepared from different starch was selected on the basis of nutrition and sensory evaluation. The shelf life of the selected soup mix was periodically evaluated at monthly intervals of three for 6 months in terms of sensory attributes and nutritional composition after packaging it in ALP.

Cost of the developed products: Cost of the developed products of the mixes were worked out based on input cost i.e. cost of different ingredients used for the preparation of soup, cost of packaging materials and over head charges@10 per cent of expenditure on manufacturing which includes labour cost, depreciation cost on machinery and equipment, building etc. was included.

Statistical analysis: In order to obtain suitable interpretation, the generated data was subjected to statistical analysis. The data on the physico-chemical characteristics of different products before and during storage 
were analyzed statistically by following Complete Randomized Design (CRD) given by Cochran and Cox (1967). While Randomised Block Design (RBD) as described by Mahony (1985) was used to analyze the data pertaining to sensory evaluation of value added products from pumpkin flour.

\section{RESULTS AND DISCUSSION}

Chemical properties of pumpkin powder: Data pertaining to chemical composition of fresh pumpkin and pumpkin powder used in the development of instant soup mix are presented in Table 3 . The concentration of $\beta$ - carotene was significantly $(0.05 \%)$ higher in pumpkin powder $(7.77 \mathrm{mg} / 100 \mathrm{~g})$ than in fresh pumpkin $(2.37 \mathrm{mg} / 100 \mathrm{~g})$. It contained 6.09 per cent moisture, 5.04 per cent protein, 2.73 per cent fat, 2.991 per cent fibre, 40.32 per cent total sugar and 16.40 per cent reducing sugar. Fresh pumpkin had 88.90 per cent moisture, 2.89 per cent protein, 0.77 per cent fat and 0.87 per cent fibre. Hart and Scott (1995) revealed that the change in composition of raw pumpkin varies according to variety, maturity, growing conditions, seasons and fraction that is consumed. However, the result obtained is more or less similar to those obtained by Pongjanta et al. (2006) and Noelia et al. (2011).

Standardization and development of instant soup mix: Four different formulations used for the standardization (Table 1) and development of Instant Soup Mix (ISM) from pumpkin powder using different proportion of ingredients such as tomato powder, onion powder, garlic powder, ginger powder and spices was subjected to sensory evaluation by a panel of ten judges (Figure 2). Based on the highest overall acceptability score (7.89), Recipe 3 was selected as the base for the incorporation of different starch viz. rice, corn and potato starch.

Standardization of method for preparation of Ready-to-serve pumpkin soup: For every 60 gram of Instant Soup Mix $750 \mathrm{ml}$ of water was required. The cooking time ranged from 2 to 3 minutes and the final product yield was $750 \mathrm{ml}$ approximately 5 serving (150 $\mathrm{ml}$ each).

Effect of different starch source on the nutritional quality and sensory attributes of instant soup mix from dehydrated pumpkin powder: The proximate composition of three different type of soup mix is presented in Table 4. Moisture content of the prepared soup mix ranged from 4.48 to 4.91 per cent. The protein and $\beta$-carotene of soup powder was maximum (12.65 and $7.01 \%$, respectively) in corn based soup mix. The overall acceptability (Table 5) of corn based instant soup mix (7.94) was higher as compared to other soup mixes. The other sensory parameters i.e. colour, flavour and texture was also utmost in corn based soup mix. Therefore, based on the nutrient composition and sensory quality parameters, corn based soup mix was selected for the storage study for a period of six month after packing in Aluminium laminated pouches (ALP).

Effect of storage on the nutritional quality and sensory attributes of instant soup mix: The result in Table 6 shows significant change in different nutritional parameters during the storage period of six month. There was increase in moisture (from 4.91 to $5.18 \%$ ), reducing sugars (from 12.31 to $12.50 \%$ ), fibre( 1.24 to $1.19 \%$ )and water activity (0.341 to 0.342$)$. While, total sugars (from 39.85 to $37.73 \%$ ), protein (from 12.65 to $12.25 \%$ ), $\beta$-carotene (from 7.01 to 6.35 $\mathrm{mg} / 100 \mathrm{~g}$ ) and fat (from 1.26 to $1.15 \%$ ) decreased with the increase in storage period. Increase in moisture

Table 1. Development and standardization of recipe for preparation of Instant Soup Mix.

\begin{tabular}{lcccc}
\hline \multirow{2}{*}{ Ingredients (g) } & \multicolumn{3}{c}{ Recipes } \\
\cline { 2 - 5 } & Recipe 1 & Recipe 2 & Recipe 3 & Recipe 4 \\
\hline Roasted pumpkin powder & 20 & 20 & 20 & 20 \\
Roasted moong dhal powder & 5 & 5 & 5 & 5 \\
Tomato powder & 12 & 13 & 15 & 16 \\
Salt & 6 & 7 & 8 & 8.5 \\
Ginger powder & 0.70 & 0.80 & 0.85 & 0.90 \\
Garlic powder & 0.70 & 0.80 & 0.85 & 0.90 \\
Onion powder & 0.70 & 0.80 & 0.85 & 0.90 \\
Black pepper powder & 0.75 & 0.85 & 0.85 & 0.90 \\
Dried pea & 2 & 2 & 2 & 2 \\
Dried spinach & 2 & 2 & 2 & 2 \\
Dried carrot & 2 & 2 & 2 & 2 \\
\hline
\end{tabular}

Table 2. Methods for analysis of different nutritional parameters of Instant soup mix.

\begin{tabular}{ll}
\hline Nutritional Parameters & Reference \\
\hline Moisture & AOAC (1990) \\
Reducing sugar & AOAC (1990) \\
Total sugar & AOAC (1990) \\
B-carotene & Ranganna (1997) \\
Protein & Kjeldhal method (Ranganna, 1997) \\
Fat & Soxhlet extraction apparatus \\
Water activity & Computer digital water activity meter $\left(\mathrm{HW}_{3}\right.$ model, Rotronic International, Switzerland) \\
\hline
\end{tabular}


during storage may be due to absorption of small quantities of moisture, by the stored products, from the atmosphere through diffusion of vapours from the microscopic spores of packaging material (Sharma et al., 2013). The gradual increase in reducing sugars during 6 months of storage might be due to the inversion of non - reducing sugars into reducing sugars and the conversion of polysaccharides to monosaccharide (Colonna et al., 1989). Increase in moisture and maillard reaction during storage is considered as a cause for decreasing protein content during storage. Similar reason was responsible for decreasing total sugar during storage. Decrease in $\beta$-carotene during storage is attributed to its oxidation (Sharma et al., 2000), while decrease in fat may be due to fat oxidation (Leelavathi

Table 3. Chemical composition of fresh pumpkin and pumpkin powder.

\begin{tabular}{lll}
\hline Characteristics & $\begin{array}{l}\text { Fresh pumpkin } \\
\text { (Mean+S.E) }\end{array}$ & $\begin{array}{l}\text { Pumpkin powder } \\
\text { (Mean +S.E) }\end{array}$ \\
\hline Moisture (\%) & $88.90 \pm 0.01$ & $6.09+0.04$ \\
Protein (\%) & $2.89 \pm 0.13$ & $5.04+0.06$ \\
Fat (\%) & $0.77 \pm 0.015$ & $2.73+0.28$ \\
Fibre (\%) & $0.87 \pm 0.02$ & $2.91 \pm 0.01$ \\
$\beta$-carotene (mg/100 g) & $2.37 \pm 0.12$ & $7.77+0.31$ \\
Total sugars (\%) & $4.85 \pm 0.01$ & $40.32+0.75$ \\
Reducing sugars (\%) & $2.05 \pm 0.01$ & $16.40+0.05$ \\
\hline
\end{tabular}

et al., 1984). Although the water activity increased during storage due to increase in moisture content of sample but it was non-significant and the product was still acceptable after 6 months.

The result of storage shows that the soup mix was organoleptically acceptable upto six month of storage study (Table 6). Although there was slight fading in colour of soup mix which is due to oxidation of $\beta$ carotene during storage, but it was still acceptable by the consumer. There was very less change in texture and flavour of soup mix. It is expected that better packaging condition will retain these characteristic of soup mix for better acceptability.

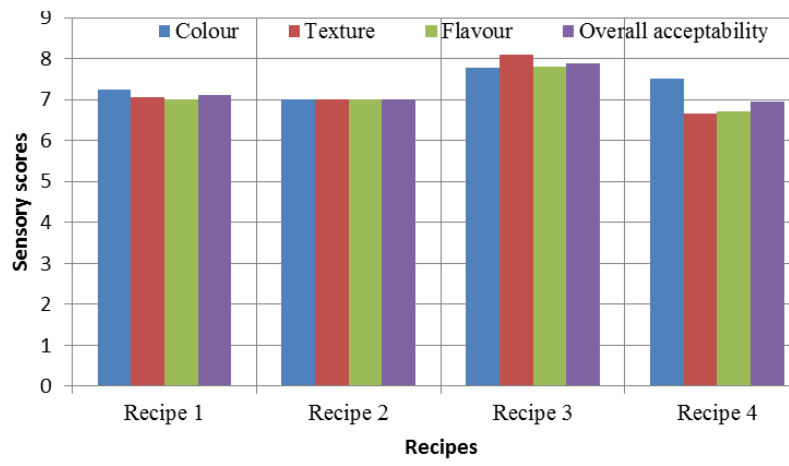

Fig. 1. Sensory evaluation of Instant Soup Mix developed from pumpkin powder.

Table 4. Effect of different starch source on the nutrition composition of Instant Soup mix from dehydrated pumpkin powder.

\begin{tabular}{lcccc}
\hline \multirow{2}{*}{ Nutrients } & \multicolumn{3}{c}{ Instant soup mix } & \multirow{2}{*}{ CD $_{\mathbf{0 . 0 5}}$} \\
\cline { 2 - 4 } & Rice based & Corn based & Potato based & 0.01 \\
Moisture (\%) & 4.48 & 4.91 & 4.67 & 0.03 \\
Total sugar (\%) & 37.48 & 39.85 & 39.63 & 0.05 \\
Reducing sugar (\%) & 10.26 & 12.31 & 15.45 & 0.09 \\
Protein (\%) & 10.50 & 12.65 & 9.52 & 0.04 \\
$\beta$-carotene (mg / 100 g) & 6.92 & 7.01 & 6.99 & 0.02 \\
Fat (\%) & 1.38 & 1.26 & 1.68 & 0.001 \\
Fibre (\%) & 1.09 & 1.24 & 1.12 & $\mathrm{NS}$ \\
Water activity & 0.339 & 0.341 & 0.356 & \\
\hline
\end{tabular}

Table 5. Effect of different starch source on the sensory attributes of Instant Soup mix from dehydrated pumpkin powder.

\begin{tabular}{lcccc}
\hline \multirow{2}{*}{ Sensory Attributes } & \multicolumn{3}{c}{ Treatments } & \multirow{2}{*}{ CD $_{\mathbf{0 . 0 5}}$} \\
\cline { 2 - 4 } & Rice based & Corn based & Potato based & 0.09 \\
Colour & 7.73 & 7.94 & 7.91 & 0.02 \\
Texture & 7.47 & 7.51 & 7.44 & 0.01 \\
Flavor & 7.94 & 8.02 & 7.91 & 0.01 \\
Overall acceptability & 7.62 & 7.94 & 7.60 & 0.001 \\
\hline
\end{tabular}

Table 6. Effect of storage at ambient temperature on the nutritional quality of Instant Soup Mix from dehydrated pumpkin powder.

\begin{tabular}{|c|c|c|c|c|c|}
\hline \multirow{2}{*}{ Nutrients } & \multicolumn{3}{|c|}{ Storage period } & \multirow[b]{2}{*}{ Mean } & \multirow[b]{2}{*}{$\mathrm{CD}_{0.05}$} \\
\hline & 0 month & 3 month & 6 month & & \\
\hline Moisture (\%) & 4.91 & 4.96 & 5.18 & 4.86 & 0.02 \\
\hline Total sugar (\%) & 39.85 & 38.02 & 37.73 & 37.88 & 0.03 \\
\hline Reducing sugar (\%) & 12.31 & 12.47 & 12.50 & 12.42 & 0.05 \\
\hline Protein $(\%)$ & 12.65 & 12.30 & 12.25 & 6.10 & 0.09 \\
\hline$\beta$-carotene $(\mathrm{mg} / 100 \mathrm{~g})$ & 7.01 & 6.75 & 6.35 & 6.64 & 0.01 \\
\hline Fat (\%) & 1.26 & 1.20 & 1.15 & 4.31 & 0.01 \\
\hline Fibre (\%) & 1.24 & 1.21 & 1.19 & 1.21 & 0.01 \\
\hline Water activity & 0.341 & 0.341 & 0.342 & 0.341 & NS \\
\hline
\end{tabular}


Cost of production of instant soup mix: For the preparation of $60 \mathrm{~g}$ Instant Soup Mix, the cost of production was calculated to be Rs. 45.28.

\section{Conclusion}

From the above study it is evident that dehydrated pumpkin powder can be effectively used in the preparation of $\beta$-carotene $(7.01 \mathrm{mg} / 100 \mathrm{~g})$ and protein $(12.65$ $\%$ ) rich soup mix. It can be done by appropriate processing and optimization of pumpkin powder along with other ingredients in correct proportions. It was also observed that the acceptability of soup mix in terms of colour, flavour and texture was also higher even after the storage of six month. The formulated soup mix only required 3-4 minute for the preparation and was also relatively of low cost. Therefore, they are very convenient in this scenario where the increase in ready-to-eat food is important for reducing the pressure of working population.

\section{ACKNOWLEDGEMENTS}

We gratefully acknowledge the financial support of the Department of Science and Technology (DST), New Delhi, India, through their Project "Development of low cost value added processed products from ripe pumpkin (Curcurbita moschata) and dissemination of technology to the farm women of Himachal Pradesh".

\section{REFERENCES}

Sowjanya, K. and Manjula, K. (2016). Standardization and development of instant ragidosa mix with dehydrated green leafy vegetables. J. Environ. Sci. Toxi. and Food Technol., 10(5): 4-8.

Semwal, A. D., Sharma, G. K, Patki, P. E., Padmashree, A. and Arya, S. S. (2001). Studies on development and storage stability of instant vegetable pulav mix. J. Food Sci. and Technol., 38. 231-234.

Patki, P. E., Srihari, P. and Arya, S. S. (2002). Studies on development of instant whole legumes. Indian Food Packers, 56: 72-79

Prapluettrakul, B., Tungtrakul, P., Panyachan, S and Limsuwan, T. (2012). Development of instant rice for young children. Sil. U Sci. and Technol. J,, 6(1): 49-58

Akoth, O. C., Oduor, S., Mwasareu, M. A., Ochieng, J. K. and Mathooko, F. M. (2012). Development of instant breakfast cereals from optimized flour of pearl millet red and white sorghum. J. of Applied Biosci., 51: 35593566

Satter, M.A., Jabin, S. A., Nusrat, Arzu, T., Mitra, T., Abdulla, A. M. and Paul, D. K. (2013). Development of nutritionally enriched instant weaning food and its safety aspect. African J. of Food Sci.,7(8): 238-249

Chandrajith, U. G., Bandaru, D. M. S. P.,Jayathunge, K. G. L. R. and Thilakaratne, B. M. K. S.(2014). Development and quality evaluation of instant rice noodles (cup noodles). Int. Res. Symposium on Postharvest Technol., 5: 8

Lohekar, A. S. and Arya, A. B. (2014). Development of value added Instant Dhokla Mix. Int $J$ Food and Nutri
Sci., 4(3): 78-83

Sunyoto, M., Futiawati, R. and Rahimah, S. (2012). The Influence of Full Cream Milk Powder Concentration to the Characteristics of "Rasi" Instant Cream Soup. J Agric Sci and Technol., 2: 1218-1231

Dhiman, A.K., Sharma, K.D. and Surekha, Attri. (2009). Functional constituents and processing of pumpkin-a review. J Food Sci and Technol., 46: 411-417

NHB. 2016. Indian horticulture database. Ministry of Agriculture, Government of India 85, Industrial Area, Sector -18 , Gurgaon-122015 India.

Anonymous. 2013. Area and production of fruits and vegetables. Directorate of Horticulture, Navbahar, Shimla.

Yadav, M., Jain, S., Tomar1, R., Prasad, G. B. K. S. and Yadav, H. (2010). Medicinal and biological potential of pumpkin: an updated review. Nut. Res. Rev., 23: 184 190. http://dx.doi:10.1017/S0954422410000107.

Blumberg, J. B. (1995). Consideration of scientific substantiation for antioxidant vitamins and beta-carotene in disease prevention. Am. J. Clinical Nut., 62: 1521 -1526.

Kim, M. Y., Kim, E. J., Kim,Y. N., Choi, C. and Lee. B. H. (2012). Comparison of the chemical compositions and nutritive values of various pumpkin (Cucurbitaceae) species and parts. Nutr Res Pract., 6(1): 21-27, http:// dx.doi.org/10.4162/nrp.2012.6.1.21.

Lal, G., Siddappa, G. S. and Tandon. G. L. (1986). Jams Jellies and marmalades. Preservation of fruits and vegetables, ICAR New Delhi Publication, pp. 294-301.

Amerine, M. A., Pangborn, R. M. and Roessler, E. B. (1965). Principles of sensory evaluation of food, Academic Press, London. pp. 236-268.

AOAC. 2004. Approved methods of association of official analytical chemists. Washington D.C. U.S.A. 11th edition.

Ranganna, S. (1997). Handbook of analysis and quality control for fruit and vegetable products, $2^{\text {nd }}$ ed. Tata McGraw Hill Publishing Company Limited, New Delhi, India, $1112 \mathrm{p}$

Cochran, W. G. and Cox, C. M. (1967). Experimental Design, John Wiley and Sons, New York, pp. 171-217.

Mahony, M. O. (1985). Sensory evaluation of food: statistical methods and procedures. Marcel Dekker, New York. pp. 168-169.

Hart, D. J. and Scott, K. J. (1995) Development and evaluation of an HPLC method for the analysis of carotenoids in foods, and the measurement of the carotenoid content of vegetables and fruits commonly consumed in the UK. Food Chem., 54:101-111

Pongjanta, J., Naulbunrang, A., Kawngdang, S., Manon, T. and Thepjaikat, T. (2006). Utilization of pumpkin powder in bakery products. $J$ Sci. Technol., 28(1): 71-79

Noelia, J. V., Jose, Z. M., Jose Alberto, G.I., Floridelia, A. G., Irma Leticia, C. H., Nuria Elizabeth, R. G. and Ruben Francisco, G. L. (2011). Chemical and Physicochemical Characterization of Winter Squash (Cucurbita moschataD.). Notulae Botanicae Horti Agrobotanici Cluj-Napoca., 39(1): 34-40

Sharma, S. K., Chaudhary, S. P., Rao V. K., Yadav V. K., and Bisht, T. S. (2013). Standardization of technology for preparation and storage of wild apricot fruit bar. J Food Sci Technol., 50(4): 784-790 doi: 10.1007/ s13197-011-0396-y

Colonna, P., Tayeb, J. and Mercier, C. (1989). Extrusion 
Anju K. Dhiman et al. / J. Appl. \& Nat. Sci. 9 (3): 1815 -1820 (2017)

cooking of starch and starchy products. In: Extrusion Cooking C Mercier, P Linko \& J.M. Harper: American Association of Cereal Chemists, Inc. pp. 247-319

Sharma, G. K., Semwal, A. D. and Arya, S. S. (2000). Effect of processing treatments on the carotenoid composition of dehydrated carrots. J. Food Sci. and Technol., 37(2): 196-200.

Leelavathi, K., Rao, P. H., Indrani, D. and Shurpalekar, S. R. (1984). Phyisio-chemical changes in whole-wheat flour (Atta) and resultant atta during storage. J. Food Sci. and Technol., 21: 10-14. 